JURNAL EKONOMI

EFEKTIF
ISSN : $2622-8882$, E-ISSN : 2622-9935

Jurnal Ekonomi Efektif, Vol. 2, No. 1, Oktober 2019

@.Prodi Manajemen Fakultas Ekonomi Universitas

Pamulang

\title{
PENGARUH MOTIVASI DAN DISIPLIN KERJA TERHADAP KINERJA KARYAWAN PT. BANK DINAR INDONESIA
}

\author{
${ }^{1}$ I Nyoman Marayasa, Anggi Faradila \\ 1'marayasa569@gmail.com
}

\begin{abstract}
ABSTRAK
Tujuan dari penelitian ini adalah untuk mengetahui Pengaruh Motivasi terhadap kinerja, Disiplin terhadap kinerja serta pengaruh Motivasi dan Disiplin secara bersama-sama terhadap Kinerja Karyawan pada PT. Bank Dinar Indonesia. Metode Penelitian yang digunakan dalam penelitian ini bersifat deskriptif kuantitatif, yaitu dengan mendeskripsikan keadaan responden serta deskripsi variabel penelitian dengan populasi sebanyak 51 orang dan sampel sebanyak 51 orang menggunakan sampel jenuh. Teknik analisis data menggunakan uji validitas, realibilitas, uji asumsi klasik, regresi berganda, koefisien determinasi $\left(\mathrm{R}^{2}\right)$, uji F, dan uji t. Hasil penelitian ini menunjukkan dua variabel independen yang di uji berpengaruh secara bersama-sama positif dan signifikan terhadap satu variabel dependen melalui uji $\mathrm{F}$ dan uji $\mathrm{t}$, sedangkan angka Adjusted R Square sebesar 0,394 menunjukkan 39,4\% variasi atas kinerja yang dapat dijelaskan oleh kedua variabel independen tersebut, dimana sisanya 60,6\% dijelaskan oleh variabel lain diluar penelitian ini. Kesimpulan penelitian yang telah dilakukan hasil penelitian menunjukkan bahwa Motivasi dan Disiplin secara parsial dan simultan memiliki pengaruh yang postif terhadap kinerja karyawan pada PT. Bank Dinar Indonesia.
\end{abstract}

\section{Kata kunci: Motivasi, Disiplin dan Kinerja Karyawan}

\section{ABSTRACT}

The purpose of this study was to determine the effect of motivation on performance, discipline on performance and the influence of motivation and discipline together on employee performance at PT. Bank Dinar Indonesia. The research method used in this study is quantitative descriptive, namely by describing the state of the respondent as well as a description of the variables of the study with a population of 51 people and a sample of 51 people using saturated samples. Data analysis technique uses validity, reliability, classic assumption test, multiple regression, determination coefficient (R2), $F$ test, and t test. The results of this study indicate that the two independent variables tested have a positive and significant effect on one dependent variable through the $F$ test and t test, while the Adjusted $R$ Square number of 0.394 shows $39.4 \%$ variation in performance that can be explained by both variables independent, where the remaining $60.6 \%$ is explained by other variables outside this research. The conclusion of the research that has been carried out the results of the research shows that Motivation and Discipline partially and simultaneously have a positive influence on the performance of employees at PT. Bank Dinar Indonesia.

Keywords: Motivation, Discipline and Employee Performance 


\section{PENDAHULUAN}

\section{A. Latar Belakang}

Motivasi karyawan berarti memberikan dorongan pada karyawan sehingga mau bekerja dengan baik. Pemberian motivasi kepada tenaga kerja dapat meningkatkan kedisiplinan tenaga kerja tersebut. Tujuan motivasi yaitu dapat meningkatkan moral dan kepuasan kerja karyawan meningkatkan produktifitas, mempertahankan kestabilan karyawan perusahaan, meningkatkan kedisiplinan tenaga kerja, mendapatkan suasana dan hubungan kerja yang baik, meningkatkan loyalitas, kreatifitas, partisipasi karyawan, mempertinggi rasa tanggung jawab karyawan terhadap tugas-tugasnya serta meningkatkan alat-alat dan bahan baku.

Terdapat karyawan yang tidak disiplin dimana jumlah karyawan yang datang terlambat masih terlalu besar yaitu sebanyak 44 kali dan di susul oleh karyawan yang sakit sehingga hal ini dapat mempengaruhi kinerja karyawan tersebut, dimana kerja karyawan ikut menurun dan tidak mencapat target yang ditentukan oleh perushaan.”Disiplin kerja merupakan kebijakan bergeser individu untuk menjadi diri bertanggung jawab untuk mematuhi peraturan lingkungan (organisasi), Setyaningdyah (2013:145)". Hal ini sejalan dengan pendapat dari "Rivai \& Sagala (2013:825) yang mengatakan bahwa disiplin kerja adalah suatu alat yang digunakan para manajer untuk berkomunikasi dengan karyawan agar mereka bersedia untuk mengubah suatu perilaku dan untuk meningkatkan kesadaran juga kesediaan seseorang agar menaati semua peraturan dan norma sosial yang berlaku di suatu perusahaan". Maka dari itu pihak manajemen harus dapat mendorong kesadaran dan kesediaan para anggotanya untuk mentaati semua peraturan yang telah ditentukan oleh organisasi atau perusahaan dan normanorma sosial yang berlaku secara sukarela. "Karena semakin baik disiplin yang dilakukan oleh karyawan disuatu perusahaan, maka semakin besar prestasi kerja yang dapat dihasilkan. Sebaliknya, tanpa disiplin yang baik, sulit bagi perusahaan mencapai hasil yang optimal, Rivai \& Sagala (2013:824)"

Kedisiplinan harus ditegaskan dalam suatu organisasi perusahaan. Tanpa dukungan disiplin karyawan yang baik, sulit perusahaan untuk mewujudkan tujuannya. Jadi, kedisiplinan adalah kunci keberhasilan suatu perusahaan dalam mencapai tujuannya. Jika karyawan yang memiliki motivasi yang tinggi dan disiplin terhadap peraturan yang ada maka kinerja dari karyawan juga akan semakin baik, "kinerja merupakan hasil atau tingkat keberhasilan seseorang secara keseluruhan selama periode tertentu di dalam melaksanakan tugas dibandingkan dengan berbagai kemungkinan, seperti standar hasil kerja, target atau sasaran atau kriteria yang telah ditentukan terlebih dahulu dan disepakati bersama, Rivai dalam Muhammad Sandy (2015:12)". Menurut survey awal yang kami lakukan kinerja kerja pada PT Bank Dinar menurut hal ini nampak terlihat dari PT Bank Dinar Indonesia merupakan perusahaan dalam bidang jasa perbankan yang mengutamakan kepuasan nasabah. Untuk memberikan pelayanan yang baik untuk nasabah tentunya memerlukan karyawan yang memiliki motivasi dan disiplin yang tinggi.

Berdasarkan pada uraian tersebut di atas, maka penulis tertarik untuk mengadakan penelitian dengan judul "Pengaruh Motivasi Dan Disipilin Terhadap Kinerja Karyawan Pada PT Bank Dinar Indonesia".

\section{B. Perumusan Masalah}

Berdasarkan latar belakang penelitian, maka permasalahan dapat dirumuskan sebagai berikut:

1. Apakah terdapat pengaruh motivasi terhadap kinerja pada PT Bank Dinar Indonesia?

2. Apakah terdapat pengaruh disiplin kerja terhadap kinerja pada PT Bank Dinar Indonesia?

3. Apakah terdapat pengaruh motivasi dan disiplin secara bersama-sama terhadap kinerja karyawan pada PT Bank Dinar Indonesia? 


\section{Tujuan Penelitian}

Tujuan penelitian ini adalah untuk memberikan jawaban atas pertanyaan khusus di atas. Adapun tujuan penelitian adalah:

1. Untuk mengetahui pengaruh motivasi terhadap kinerja pada PT Bank Dinar Indonesia?

2. Untuk mengetahui pengaruh disiplin kerja terhadap kinerja pada PT Bank Dinar Indonesia?

3. Untuk mengetahui pengaruh motivasi dan disiplin secara bersama-sama terhadap kinerja karyawan pada PT Bank Dinar Indonesia?

\section{TINJAUAN PUSTAKA}

\section{A. Motivasi}

Untuk mempermudah pemahaman motivasi kerja, dibawah ini dikemukakan pengertian motif, motivasi dan motivasi kerja.

"Abraham Sperling dalam Anwar prabu (2015:93) mengemukakan bahwa "motive is defined as a tendency ti activity, started by a drive and ended by an adjustment. The adjustment is said to satisfy themovie". (motif didefinisikan sebagai suatu kecendrungan untuk beraktivitas dimulai dari dorongan dalam diri (drive) dan diakhiri dengan penyesuaian diri. Penyesuaian diri dikatakan untuk memuaskan motif)".

"William J. Santon dalam Anwar Prabu (2015:93) mendefinisikan bahwa "A Motive is a stimulated need which a goal-oriented individual seeks to satisfy". (Suatu motif adalah kebutuhan yang distimulasi yang berorientasi kepada tujuan individu dalam mencapai rasa puas)". Motivasi didefinisikan oleh "Fillmore H. Stanford dalam Anwar Prabu (2015:93) bahwa "Motivation as an energizing condition of the organism that serves to direct that organism toward the goal of a certain class" (Motivasi sebagai suatu kondisi yang menggerakan manusia ke arah suatu tujuan tertentu)".

Berdasarkan pendapat parah ahli diatas, dapat disimpulkan bahwa motif merupakan suatu dorongan kebutuhan dalam diri pegawai yang perlu dipenuhi agar para pegawai tersebut dapat menyesuaikan diri terhadap lingkungannya, sedangkan motivasi adalah kondisi yang menggerakkan pegawai agar mampu mencapai tujuan dari motifnya. Motivasi sangat penting bagi tinggi rendahnya produktivitas perusahaan. Tanpa adanya motivasi dari para karyawan untuk bekerja sama bagi kepentingan perusahaan, maka tujuan yang telah ditetapkan tidak akan tercapai. Sebaliknya, apabila terdapat motivasi yang tinggi dari para karyawan, maka hal ini merupakan suatu jaminan atas keberhasilan perusahaan dalam mencapai tujuannya.

Menurut "Hasibuan (2016:141) motivasi adalah pemberian daya penggerak yang menciptakan kegairahan kerja seseorang agar mereka mau bekerjasama, bekerja efektif, dan terintegrasi dengan segala upaya untuk mencapai kepuasan",

Menurut Edy Sutrisno (2016: 109) Motivasi adalah "suatu faktor yang mendorong seseorang untuk melakukan suatu aktivitas tertentu, oleh karena itu motivasi sering kali diartikan pula sebagai faktor pendorong perilaku seseorang."

Menurut Kadarisma (2012:278) motivasi adalah "penggerak atau pendorong dalam diri seseorang untuk mau berperilaku dan bekerja dengan giat dan baik sesuai dangan tugas dan kewajiban yang telah diberikan kepadanya".

Bagi manajemen motivasi adalah menciptakan kondisi yang mampu mendorong setiap pekerja melakukan tugas-tugasnya dengan rasa senang dan puas. Dengan kata lain manajemen sebagai proses mendayagunakan orang lain untuk mencapai suatu tujuan, hanya berlangsung efektif dan efisien, jika manager mampu memotivasi para pekerja dalam melaksanakan tugastugas dan tanggung jawabnya. Menurut "Zameer, Ali, Nisar dan Amir (2014:297), motivasi merupakan keinginan karyawan untuk melakukan sesuatu yang diberikan dan untuk menumbuhkan rasa tanggung jawab. Motivasi yang baik maka akan meningkatkan kinerja 
karyawan, selain faktor motivasi kedisiplinan juga mempengaruhi kinerja karyawan dimana karyawan yang sering datang telat dan tidak masuk maka target kerjanya tidak tercapai”.

Dari beberapa definisi tersebut diatas penulis menyimpulkan bahwa yang dimaksud dengan motivasi merupakan suatu keadaan atau kondisi yang mendorong, merangsang atau menggerakan seseorang untuk melakukan sesuatu atau kegiatan yang dilakukannya sehingga ia dapat mencapai tujuannya.

Menurut "Zameer, Ali, Nisar dan Amir (2014:297), motivasi merupakan keinginan karyawan untuk melakukan sesuatu yang diberikan dan untuk menumbuhkan rasa tanggung jawab", sedangkan indikator motivasi yang terdiri dari:

a) Gaji, adalah suatu bentuk pembayaran periodik dari seorang majikan pada karyawannya yang dinyatakan dalam suatu kontrak kerja.

b) Bonus, adalah kompensasi tambahan yang diberikan kepada seorang karyawan yang nilainya di atas gaji normalnya.

c) Jaminan Kesejahteraan Karyawan, adalah balas jasa yang diterima oleh pekerja dalam bentuk selain upah atau gaji langsung

d) Perasaan aman memiliki pekerjaan, adalah perasaan aman karena memiliki penghasilan tetap untuk bertahan hidup.

e) Promosi, adalah penghargaan dengan kenaikan jabatan dalam suatu organisasi ataupun instansi baik dalam pemerintahan maupun non pemerintah (swasta).

\section{B. Disiplin Kerja}

Pengertian disiplin kerja menurut (Keith Davis dalam Anwar Prabu 2015:129): "Discipline is management action to enforce organization standard'. Berdasarkan pendapat Keith Davis, disiplin kerja dapat diartikan sebagai pelaksanaan manajemen untuk memperteguh pedoman-pedoman organisasi.

Menurut Henry Simamora (2004:610) dalam Sari (2013): "Disiplin adalah prosedur yang mengoreksi atau menghukum bawahan karena melanggar peraturan atau prosedur. Disiplin merupakan pengendalian diri karyawan dan pelaksanaan yang teratur dan menunjukkan tingkat kesungguhan tim kerja di dalam sebuah organisasi. Tindakan disipliner menuntut suatu hukuman terhadap karyawan yang gagal memenuhi standar yang ditatapkan. Tindakan disipliner yang efektif terpusat pada perilaku karyawan yang salah, bukan pada diri karyawan sebagai pribadi".

Bagi Beach (dalam Edy Sutrisno, 2017), disiplin mempunyai dua pengertian. Arti yang pertama, melibatkan belajar atau mencetak perilaku dengan menerapkan imbalan atau hukuman. Arti kedua lebih sempit lagi, yaitu disiplin ini hanya bertalian dengan tindakan hukuman terhadap pelaku kesalahan. Dapat dirumuskan bahwa yang dimaksud dengan disiplin kerja adalah sikap hormat terhadap peraturan dan ketetapan perusahaan, yang ada dalam diri karyawan, yang menyebabkan ia dapat menyesuaikan diri dengan sukarela pada peraturan dan ketetapan perusahaan.

"Kedisiplinan adalah kunci keberhasilan suatu perusahaan dalam mencapai tujuannya. Disipilin itu sendiri merupakan merupakan kebijakan bergeser individu untuk menjadi diri bertanggung jawab untuk mematuhi peraturan lingkungan (organisasi), Setyaningdyah (2013:145)". Sedangkan indikator-Indikator yang mempengaruhi disiplin kerja menurut Simamora dalam Sari (2013) adalah sebagai berikut:

1. Kepatuhan Pada Peraturan

2. Efektif Dalam Bekerja

3. Tindakan Korektif

4. Kehadiran Tepat Waktu

5. Menyelesaikan Pekerjaan Tepat Waktu 


\section{Kinerja}

Peningkatan kinerja karyawan akan membawa kemajuan bagi perusahaan untuk dapat bertahan dalam suatu persaingan lingkungan bisnis yang tidak stabil. Oleh karena itu upayaupaya untuk meningkatkan kinerja karyawan merupakan tantangan manajemen yang paling serius karena keberhasilan untuk mencapai tujuan dan kelangsungan hidup perusahaan tergantung pada kualitas kinerja sumber daya manusia yang ada di dalamnya.

Menurut Sutrisno (2016:151) kinerja adalah "sebagai hasil yang telah dicapai seseorang dari tingkah kerjanya dalam melaksanakan aktivitas kerja". Karyawan dapat bekerja dengan baik bila memiliki kinerja tinggi, sehingga dapat menghasilkan kinerja yang baik pula. Menurut Irham Fahmi (2016:176) Kinerja adalah "hasil yang diperoleh oleh suatu organisasi baik organisasi tersebut bersifat profit oriented dan nonprofit oriented yang dihasilkan selama satu periode waktu". Menurut Bani (2013:10) pengertian kinerja (prestasi kerja) adalah "hasil kerja secara kualitas dan kuantitas yang dicapai oleh seseorang karyawan dalam melaksankan tugasnya sesuai dengan tanggung jawab yang diberikan kepadanya”. Menurut Anwar Prabu Mangkunegara (2013:67). Pengertian kinerja adalah "hasil kerja secara kualitas dan kuantitas yang dicapai oleh seorang pegawai dalam melaksanakan tugasnnya sesuai dengan tanggung jawab yang diberikan kepadanya".

Kinerja atau performance merupakan perilaku organisasi yang secara langsung berhubungan dengan aktivitas hasil kerja, pencapaian tugas dimana istilah tugas berasal dari pemikiran aktivitas yang dibutuhkan oleh pekerjaan (Hasibuan, 2011:56). Menurut Surya Dharma (2012:83), mengemukan bahwa indikator kinerja sebagai berikut: konsisten, tepat, menantang, dapat diukur, dapat dicapai, disepakati, dihubungkan dengan waktu, berorientasikan kerja kelompok. Dari pendapat ahli diatasdapat disimpulkan bahwa kinerja merupakan hasil kerja seseorang atau sekelompok orang dalam suatu organisasi, sesuai dengan wewenang dan tanggung jawab masing-masing dalam upaya mencapai tujuan organisasi.

Menurut Surya Dharma (2012:83) indikatornya adalah:

1. Konsisten : fokus akan suatu hal yang dikerjakan dan tidak berubah-ubah.

2. Tepat: menyelesaikan tugas atau pekerjaan secara benar.

3. Menantang : mengerjakan pekerjaan di luar pekerjaan yang biasa dilakukan.

4. Dapat diukur : dapat di nilai hasil kerja yang dikerjakan.

5. Dapat dicapai : pekerjaan yang dapat diselesaikan dengan baik.

6. Disepakati : disetujui pemberi kerja dan penerima pekerjaan.

7. Dihubungkan dengan waktu : mampu menyelesaikan semua tugas yang diberikan sesuai deadline yang ditentukan.

8. Berorientasikan kerja kelompok : mampu bekerjasama secara berkelompok dalam mengerjakan suatu tugas.

\section{METODE PENELITIAN}

Untuk memperoleh data dalam Penelitian ini, penulis memilih tempat penelitian dilakukan pada PT Bank Dinar Indonesia, alamat: Gedung Thamrin City Unit CT/LDI-3, Jl. KH Mas Mansyur Kebon Kacang. Adapun yang menjadi responden dalam penelitian ini adalah staff di PT Bank Dinar Indonesia.

Menurut Sugiyono (2017:389) populasi adalah "generalisasi yang terdiri atas obyek/subyek yang mempunyai kualitas dan karakteristik tertentu yang ditetapkan oleh peneliti untuk dipelajari dan kemudian ditarik kesimpulannya. Sugiyono.

Sesuai dengan penelitian yang penulis ambil, yaitu Pengaruh Motivasi dan Kompensasi terhadap Kinerja karyawan di PT Bank Dinar Indonesia, maka Populasi yang penulis ambil dalam penelitian ini adalah karyawan yang sampai saat ini masih aktif bekerja pada PT Bank Dinar Indonesia yang jumlahnya berjumlah 51 (lima puluh satu) orang. Agar data yang diambil 
representatif atau mewakili maka besarnya sampel yang akan diambil harus ditentukan dan harus mencerminkan karakteristik populasi. Sampel adalah bagian dari jumlah dan karakteristik yang dimiliki oleh populasi.

Menurut Sugiyono (2013:116) sampel adalah bagian dari jumlah dan karakteristik yang dimiliki oleh populasi tersebut. Bila populasi besar atau diatas 100 (seratus) orang, dan penelitian tidak mungkin mempelajari semua yang ada pada populasi. Oleh karena itu sampel pada PT Bank Dinar Indonesia berjumlah 51 (lima puluh satu) orang.

Dengan demikian teknik pengambilan sampel yang digunakan dalam penelitian ini adalah teknik sampling jenuh. Sampling jenuh adalah teknik penentuan sampel bila semua anggota populasi digunakan sebagai sampel (Sugiyono, 2013:124). Data yang digunakan adalah menggunakan data primer dan data skunder. Data primer yang berupa berupa penyebaran kuesioner sedangkan dari data sekunder berupa buku, website, profil perusahaan dan lainnya. Teknik pengumpulan data dengan menggunakan wawancara, observasi, studi pustaka dan kuesioner.

Metode Penelitian yang digunakan dalam penelitian ini bersifat deskriptif kuantitatif, yaitu dengan mendeskripsikan keadaan responden serta deskripsi variabel penelitian dengan populasi sebanyak 51 orang dan sampel sebanyak 51 orang menggunakan sampel jenuh. Teknik analisis data menggunakan uji validitas, realibilitas, uji asumsi klasik, regresi berganda, koefisien determinasi $\left(\mathrm{R}^{2}\right)$, uji F, dan uji t.

\section{HASIL DAN PEMBAHASAN}

\section{A. Sejarah Singkat Perusahaan}

PT Bank Dinar Indonesia Tbk merupakan salah satu Bank Umum Swasta Nasional NonDevisa yang didirikan di Jakarta pada tanggal 15 Agustus 1990 dengan Akta Notaris James Herman Rahardjo, SH. No. 99. Ijin operasi sebagai Bank Umum ditetapkan melalui surat Bank Indonesia tertanggal 22 November 1991. Pada awal berdirinya Bank ini bernama PT. Bank Liman International terhitung sejak tanggal 8 November 2012 dilakukan rebranding dari PT Bank Liman International menjadi PT Bank Dinar Indonesia (Bank Dinar). Perubahan nama ini diputuskan melalui Rapat Umum Pemegang Saham Luar Biasa (RUPSLB) tanggal 23 Mei 2012 dan telah mendapat persetujuan dari Departemen Hukum dan Hak Asasi Manusia Republik Indonesia melalui suratnya Nomor AHU-33753.AH.01.02.Tahun 2012 tanggal 20 Juni 2012, serta persetujuan perubahan ijin usaha dari Bank Indonesia melalui surat Keputusan Gubernur Bank Indonesia Nomor 14/75/KEP.GBI/2012 tanggal 25 Oktober 2012 tentang Perubahan Penggunaan Izin Usaha Atas Nama PT. Liman International Bank Menjadi Izin Usaha Atas Nama PT Bank Dinar Indonesia. Berdasarkan Akta Berita Acara Rapat Umum Pemegang Saham Luar Biasa Perseroan No. 4 tanggal 5 Juni 2014, tentang Perubahan Seluruh Anggaran Dasar Perseroan dari Status Perseroan Tertutup menjadi Terbuka, dibuat di hadapan Tjhong Sendrawan, S.H., Notaris di Jakarta, yang telah mendapat Persetujuan dan terdaftar atas Perubahan Anggaran Dasar Perseroan dari Menteri Hukum dan Hak Asasi Manusia Republik Indonesia di bawah No. AHU-03715.40.20.2014 Tahun 2014 tanggal 10 Juni 2014. Terhitung sejak tanggal 11 Juli 2014, saham PT Bank Dinar Indonesia Tbk resmi diperdagangkan di Bursa Efek Indonesia (BEI) dengan kode saham DNAR.

\section{B. Hasil Analisa}

\section{Hasil Uji Kualitas Data}

a. Uji Validitas

Uji validitas digunakan untuk mengetahui sah atau valid tidaknya suatu kuesioner. Uji validitas dilakukan dengan membandingkan nilai $r$ hitung dengan $r$ tabel untuk tingkat signifikansi 5 persen degree of freedom $(\mathrm{df})=\mathrm{n}-2$, dalam hal ini $\mathrm{n}$ 
adalah jumlah sampel. Jika $\mathrm{r}$ hitung $>\mathrm{r}$ tabel maka pertanyaan atau indikator tersebut dinyatakan valid, demikian sebaliknya bila $\mathrm{r}$ hitung $<\mathrm{r}$ tabel maka pertanyaan tersebut dinyatakan tidak valid.

Tabel. 4.1

Hasil Uji Validitas Motivasi

\begin{tabular}{|c|c|c|c|}
\hline Butir Pernyataan & r hitung & r tabel & Keterangan \\
\hline 1 & 0,432 & 0,276 & Valid \\
\hline 2 & 0,550 & 0,276 & Valid \\
\hline 3 & 0,522 & 0,276 & Valid \\
\hline 4 & 0,291 & 0,276 & Valid \\
\hline 5 & 0,695 & 0,276 & Valid \\
\hline 6 & 0,702 & 0,276 & Valid \\
\hline 7 & 0,564 & 0,276 & Valid \\
\hline 8 & 0,524 & 0,276 & Valid \\
\hline 9 & 0,662 & 0,276 & Valid \\
\hline 10 & 0,487 & 0,276 & Valid \\
\hline
\end{tabular}

Tabel 4.2

Hasil Uji Validitas Disiplin Kerja

\begin{tabular}{|c|c|c|c|}
\hline Butir Pernyataan & r hitung & r tabel & Keterangan \\
\hline 1 & 0,523 & 0,276 & Valid \\
\hline 2 & 0,507 & 0,276 & Valid \\
\hline 3 & 0,514 & 0,276 & Valid \\
\hline 4 & 0,570 & 0,276 & Valid \\
\hline 5 & 0,703 & 0,276 & Valid \\
\hline 6 & 0,699 & 0,276 & Valid \\
\hline 7 & 0,630 & 0,276 & Valid \\
\hline 8 & 0,338 & 0,276 & Valid \\
\hline 9 & 0,523 & 0,276 & Valid \\
\hline 10 & 0,507 & 0,276 & Valid \\
\hline
\end{tabular}

Tabel 4.3

Hasil Uji Validitas Kinerja

\begin{tabular}{|c|c|c|c|}
\hline Butir Pernyataan & r hitung & r tabel & Keterangan \\
\hline 1 & 0,557 & 0,276 & Valid \\
\hline 2 & 0,789 & 0,276 & Valid \\
\hline 3 & 0,652 & 0,276 & Valid \\
\hline 4 & 0,769 & 0,276 & Valid \\
\hline 5 & 0,507 & 0,276 & Valid \\
\hline 6 & 0,787 & 0,276 & Valid \\
\hline 7 & 0,789 & 0,276 & Valid \\
\hline 8 & 0,454 & 0,276 & Valid \\
\hline 9 & 0,838 & 0,276 & Valid \\
\hline 10 & 0,797 & 0,276 & Valid \\
\hline 11 & 0.476 & 0,276 & Valid \\
\hline 12 & 0,313 & 0,276 & Valid \\
\hline 13 & 0,345 & 0,276 & Valid \\
\hline 14 & 0,335 & 0,276 & Valid \\
\hline 15 & 0,316 & 0,276 & Valid \\
\hline 16 & 0,384 & 0,276 & Valid \\
\hline
\end{tabular}




\section{b. Hasil Uji Reliabilitas}

Uji reliabilitas hanya dapat dilakukan setelah suatu instrumen telah dipastikan validitasnya. Pengujian reliabilitas dalam penelitian ini untuk menunjukan tingkat reliabilitas konsistensi internal teknik yang digunakan adalah dengan mengukur koefisien Cronbach's Alpha dengan bantuan program SPSS 23. Nilai alpha bervariasi dari $0-1$, suatu pertanyaan dapat dikategorikan reliabel jika nilai alpha lebih besar dari 0,60 dalam (Ghozali, 2009:48). Berdasarkan hasil uji reliabilitas menyatakan bahwa seluruh variabel dinyatakan reliabel karena memiliki nilai cronbach alpha $>$ 0,6. Berikut hasil uji reliabilitas:

Tabel 4.4

Hasil Uji Reliabilitas

\begin{tabular}{|l|c|c|}
\hline Variabel & $\begin{array}{c}\text { Cronbach } \\
\text { Alpha }\end{array}$ & Hasil \\
\hline Motivasi & 0,733 & Reliabel \\
\hline $\begin{array}{l}\text { Disiplin } \\
\text { Kerja }\end{array}$ & 0,675 & Reliabel \\
\hline Kinerja & 0,853 & Reliabel \\
\hline
\end{tabular}

\section{Hasil Pengujian Persyaratan Analisis (Uji Asumsi Klasik)}

a. Hasil Pengujian Normalitas Data

Tabel 4.5

Hasil Uji Normalitas Secara Statistik

\begin{tabular}{|c|c|}
\hline One-Sample Kolmogo & ov-Smirnov Test \\
\hline & $\begin{array}{l}\text { Unstandardized } \\
\text { Residual }\end{array}$ \\
\hline $\mathrm{N}$ & 51 \\
\hline Normal & .0000000 \\
\hline $\begin{array}{l}\text { Parameters } \\
\mathrm{b}\end{array}$ & 5.29069091 \\
\hline Absolute & .071 \\
\hline Extreme & .061 \\
\hline Differences & -.071 \\
\hline Test Statistic & .071 \\
\hline Asymp. Sig. (2-tailed) & $200^{\mathrm{c}, \mathrm{d}}$ \\
\hline a. Test distribution is $\mathrm{N}$ & \\
\hline b. Calculated from dat & \\
\hline
\end{tabular}

Berdasarkan uji kolmogorov-smirnov dapat diketahui bahwa seluruh variabel memiliki nilai sig. $>0,05$, ini mengartikan bahwa semua data terdistribusi dengan normal.

b. Hasil Pengujian Multikolinearitas

Berikut hasil uji multikoloniaritas:

Tabel 4.6

Uji Multikolinieritas

\begin{tabular}{|c|c|c|c|c|c|c|c|}
\hline \multicolumn{8}{|c|}{ Coefficients $^{\mathrm{a}}$} \\
\hline \multirow[b]{2}{*}{ Model } & \multicolumn{2}{|c|}{$\begin{array}{l}\text { Unstandardized } \\
\text { Coefficients }\end{array}$} & \multirow{2}{*}{$\begin{array}{l}\text { Standardized } \\
\text { Coefficients } \\
\text { Beta }\end{array}$} & \multirow[b]{2}{*}{$t$} & \multirow[b]{2}{*}{ Sig. } & \multicolumn{2}{|c|}{$\begin{array}{c}\text { Collinearity } \\
\text { Statistics }\end{array}$} \\
\hline & B & $\begin{array}{l}\text { Std. } \\
\text { Error }\end{array}$ & & & & Tolerance & VIF \\
\hline \begin{tabular}{l|l}
1 & (Constant) \\
\end{tabular} & 11.203 & 9.088 & & 1.233 & .224 & & \\
\hline
\end{tabular}




\begin{tabular}{|l|l|r|r|rr|r|r|r|r|}
\hline MOTIVASI & .610 & .227 & & .360 & 2.683 & .010 & .671 & 1.490 \\
\hline & DISIPLIN & .811 & .296 & & .369 & 2.745 & .008 & .671 & 1.490 \\
\hline
\end{tabular}

Tabel di atas menjelaskan bahwa data yang ada tidak terjadi gejala multikolinearitas antara masing-masing variabel independen yaitu dengan melihat nilai $V I F$. Nilai $V I F$ yang diperbolehkan hanya mencapai 10 maka data di atas dapat dipastikan tidak terjadi gejala multikolinearitas. Karena data di atas menunjukan bahwa nilai VIF lebih kecil dari 10 dan nilai tolerance lebih besar dari 0,10 keadaan seperti itu membuktikan tidak terjadinya multikolinearitas.

c. Hasil Pengujian Hetroskedastisitas

Uji heteroskedastisitas bertujuan untuk menguji apakah dalam model regresi terjadi ketidaksamaan variance dari residual satu pengamatan yang lain, berikut hasil pengujian

\section{Tabel 4.7}

Uji hetroskedastisitas Model Summary

\begin{tabular}{|c|c|c|c|c|}
\hline $\begin{array}{l}\text { Mo } \\
\text { del }\end{array}$ & $\mathrm{R}$ & $\begin{array}{c}\text { R } \\
\text { Squar } \\
\text { e }\end{array}$ & $\begin{array}{l}\text { Adjusted } \\
\text { R Square }\end{array}$ & $\begin{array}{l}\text { Std. } \\
\text { Error of } \\
\text { the } \\
\text { Estimate }\end{array}$ \\
\hline 1 & $.647^{\mathrm{a}}$ & .418 & .394 & 5.39979 \\
\hline
\end{tabular}

a. Predictors: (Constant), DISIPLIN, MOTIVASI

b. Dependent Variable: KINERJA

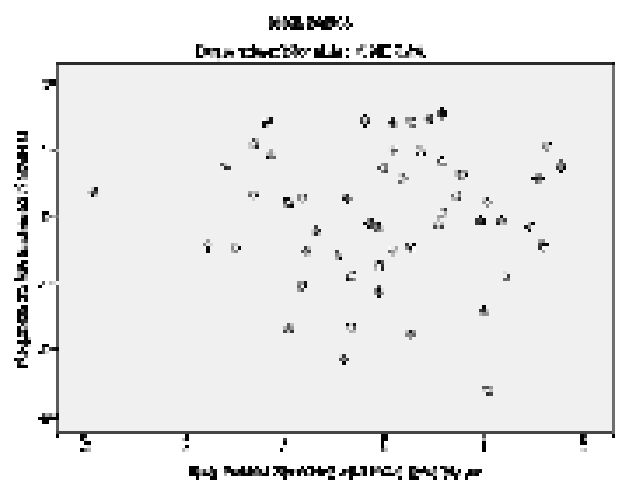

Gambar 4.1 Scatter Plot

Dari grafik scatterplot yang ditampilkan pada gambar diatas dapat disimpulkanbahwa terjadi homoskedastisitas karena titik-titik yang ada menyebar secara acak tanpa ada pola pola tertentu yang teratur.

Secara keseluruhan dengan hasil uji yang telah ditentukan dapat disimpulkan bahwa tidak mengalami heteroskedastisitas. Jadi dapat disimpulkan data dinyatakan lolos dari uji asumsi klasik.

\section{Hasil Koefisien Persamaan Regresi Linier Berganda}

Berikut adalah hasil koefisien regresi linier berganda:

$$
Y=11,203+0,610 . X_{1}+0,811 . X_{2}+e
$$

Keterangan :

$\mathrm{Y}=$ Kinerja karyawan

$\mathrm{a}=$ Nilai konstanta 
$\mathrm{b} 1=$ Koefisien regresi variabel $\mathrm{X} 1$

$\mathrm{b} 2=$ Koefisien regresi variabel X2

$\mathrm{X} 1=$ Variabel Motivasi

$\mathrm{X} 2=$ Variabel Disiplin Kerja

Persamaan regresi linier tersebut dapat menunjukkan hasil bahwa variabel Motivasi Dan Disiplin Kerja bernilai positif terhadap Kinerja Karyawan. Artinya apabila variabel Motivasi dan Disiplin Kerja ditingkatkan, maka meningkat pula Kinerja Karyawan

Tabel 4.8

Regresi Linier Berganda

Coefficients $^{\text {a }}$

\begin{tabular}{|c|c|c|c|c|c|c|c|}
\hline \multirow[b]{2}{*}{ Model } & \multicolumn{2}{|c|}{$\begin{array}{c}\text { Unstandardized } \\
\text { Coefficients } \\
\end{array}$} & \multirow{2}{*}{\begin{tabular}{|c}
$\begin{array}{c}\text { Standardized } \\
\text { Coefficients }\end{array}$ \\
Beta \\
\end{tabular}} & \multirow[b]{2}{*}{$\mathrm{t}$} & \multirow[b]{2}{*}{ Sig. } & \multicolumn{2}{|c|}{$\begin{array}{c}\text { Collinearity } \\
\text { Statistics }\end{array}$} \\
\hline & B & $\begin{array}{l}\text { Std. } \\
\text { Error }\end{array}$ & & & & Tolerance & VIF \\
\hline 1 (Constant) & 11.203 & 9.088 & & 1.233 & .224 & & \\
\hline MOTIVASI & .610 & .227 & .360 & 2.683 & .010 & .671 & 1.490 \\
\hline DISIPLIN & .811 & .296 & .369 & 2.745 & .008 & .671 & 1.490 \\
\hline
\end{tabular}

a. Dependent Variable: KINERJA

\section{Hasil Koefisien Determinasi (Adjusted $\boldsymbol{R}^{2}$ )}

Berikut adalah hasil koefisien Determinasi (Adjusted $R^{2}$ ):

untuk mengetahui seberapa besar kemampuan variabel dependen, dan hasil yang didapatkan menunjukan nilai $\mathrm{R}^{2}$ (koefisien determinasi yang sudah disesuaikan) 0,394 artinya 39,40\% variabel Kinerja Karyawan dapat dijelaskan oleh varibel Motivasi dan Disiplin dan sisanya 60,6\% (100\%-39,40\%) dijelaskan oleh variabel lain diluar variabel yang digunakan.

\section{Hasil Pengujian Hipotesis}

a. Hasil Uji T (Pengujian Secara Parsial)

Tabel 4.9

Uji T

Coefficients $^{\text {a }}$

\begin{tabular}{|c|c|c|c|c|c|c|c|}
\hline \multirow[b]{2}{*}{ Model } & \multicolumn{2}{|c|}{$\begin{array}{c}\text { Unstandardized } \\
\text { Coefficients } \\
\end{array}$} & \multirow{2}{*}{$\begin{array}{c}\begin{array}{c}\text { Standardized } \\
\text { Coefficients }\end{array} \\
\text { Beta } \\
\end{array}$} & \multirow[b]{2}{*}{$\mathrm{T}$} & \multirow[b]{2}{*}{ Sig. } & \multicolumn{2}{|c|}{$\begin{array}{c}\text { Collinearity } \\
\text { Statistics }\end{array}$} \\
\hline & B & $\begin{array}{l}\text { Std. } \\
\text { Error }\end{array}$ & & & & Tolerance & VIF \\
\hline 1 (Constant) & 11.203 & 9.088 & & 1.233 & .224 & & \\
\hline MOTIVASI & .610 & .227 & .360 & 2.683 & .010 & .671 & 1.490 \\
\hline DISIPLIN & .811 & .296 & .369 & 2.745 & .008 & .671 & 1.490 \\
\hline
\end{tabular}

a. Dependent Variable: KINERJA

Dari tabel diatas didapatkan hasil sebagai berikut:

1) Variabel Motivasi memiliki nilai thitung $>$ dari t tabel yaitu 2,683 $>2,008$ dengan nilai probabilitas $(0,01 \leq 0,05)$ artinya signifikan atau dengan kata lain $\mathrm{H}_{\mathrm{a}}$ diterima $\mathrm{H}_{\mathrm{O}}$ ditolak. Jadi Motivasi secara parsial berpengaruh dan signfikan terhadap kinerja karyawan PT Bank Dinar Indonesia. 
2) Variabel Disiplin memiliki nilai t hitung $>$ dari t tabel yaitu 2,745 $>2,008$ dengan nilai probabilitas $(0,01 \leq 0,05)$ artinya signifikan atau dengan kata lain $\mathrm{H}_{\mathrm{a}}$ diterima Ho ditolak. Jadi Disiplin Kerja secara parsial berpengaruh dan signfikan terhadap kinerja karyawan PT Bank Dinar Indonesia.

b. Hasil Uji F (Pengujian Secara Simultan)

Tabel 4.10

Uji F

ANNOVA

\begin{tabular}{|l|c|r|c|c|c|}
\hline Model & $\begin{array}{c}\text { Sum of } \\
\text { Squares }\end{array}$ & df & $\begin{array}{c}\text { Mean } \\
\text { Square }\end{array}$ & F & Sig. \\
\hline 1 Regression & 1007.057 & 2 & 503.528 & 17.269 & $.000^{\mathrm{b}}$ \\
Residual & 1399.571 & 48 & 29.158 & & \\
Total & 2406.627 & 50 & & & \\
\hline
\end{tabular}

a. Dependent Variable: KINERJA

b. Predictors: (Constant), DISIPLIN, MOTIVASI

Dari uji ANNOVA atau F test diketahui bahwa F hitung 17,269 lebih besar dari F tabel 3,18 menunjukkan, variabel independen bersama-sama berpengaruh terhadap variabel dependen jika $\alpha$ atau nilai probabilitas (pada kolom sig) lebih kecil dari pada level signifikan yang ditentukan yaitu 0,05. Dari hasil output SPSS diatas, nilai probabilitas $(\alpha) 0,000 \leq 0,05$ maka memiliki arti bahwa ada pengaruh yang signifikan, menurut Ghozali dalam Arasyd (2013:34).

Jadi Motivasi dan Disiplin Kerja secara bersama-sama memiliki pengaruh terhadap Kinerja Karyawan PT Bank Dinar Indonesia.

\section{KESIMPULAN DAN SARAN}

\section{A. Kesimpulan}

Berdasarkan hasil dan pembahasan mengenai pengaruh Motivasi dan Disiplin Kerja terhadap kinerja karyawan, maka penulis menyimpulkan beberapa hal setelah dilakukan penelitian dengan pengolahan data yang digunakan sebagai berikut:

1. Motivasi berpengaruh positif dan signifikan terhadap kinerja karyawan PT Bank Dinar Indonesia. Hal ini dibuktikan nilai t hitung $>$ dari $t$ tabel yaitu 2,474 $>1,669$ dengan nilai probabilitas $(0,01 \leq 0,05)$ artinya signifikan atau dengan kata lain $\mathrm{H}_{\mathrm{a}}$ diterima $\mathrm{Ho}_{\mathrm{O}}$ ditolak.

2. Disiplin Kerja berpengaruh positif dan signifikan terhadap kinerja karyawan PT Bank Dinar Indonesia. Hal ini Hal ini dibuktikan nilai t hitung $>$ dari $t$ tabel yaitu 5,478 $>1,669$ dengan nilai probabilitas $(0,01 \leq 0,05)$ artinya signifikan atau dengan kata lain $\mathrm{H}_{\mathrm{a}}$ diterima $\mathrm{H}_{O}$ ditolak.

3. Motivasi dan Disiplin Kerja secara Bersama-sama berpengaruh positif dan signifikan terhadap kinerja karyawan PT Bank Dinar Indonesia. Hal ini dibuktikan dengan F hitung 16,824 lebih besar dari $\mathrm{F}$ tabel 3,14 dan nilai probabilitas (pada kolom sig) lebih kecil dari pada level signifikan ditentukan yaitu 0,05 .

\section{B. Saran}

Berdasarkan hasil penelitian, adapun saran-saran yang ingin penulis berikan untuk meningkatkan kinerja karyawan hendaknya perusahaan atau pimpinan lebih memperhatikan yaitu: 
1. Untuk indikator promosi sebaiknya perusahaan memberi kesempatan kepada karyawan yang berprestasi untuk kenaikan jabatan.

2. Untuk indikator kepatuhan pada peraturan sebaiknya perusahaan lebih tegas dalam memberikan sanksi bagi karyawan yang tidak menjalankan prosedur perusahaan dengan baik.

3. Untuk indikator yang dihubungkan dengan waktu sebaiknya perusahaan membuat pekerjaan memiliki deadline yang lebih fleksible dalam menyelesaikan pekerjaan.

4. Untuk penelitian selanjutnya dianjurkan untuk menambah variabel-variabel yang belum digunakan dalam penelitian yang mempengaruhi kinerja karyawan dan melakukan observasi dan percobaan pengolahan data terlebih dahulu, karena tidak semua data perusahaan yang ada memilliki distribusi normal sehingga penelitian tidak akan terbentur oleh data sampel dibawah 51.

\section{DAFTAR PUSTAKA}

Anwar, AA Prabu Mangkunegara. Manajemen Sumber Daya Manusia Perusahan. Bandung, PT. Remaja Rodakarya. 2015

Alfajar, Siti dan Tri Heru. Manajemen Sumber daya Manusia Sebagai dasar Dasar Meraih Keunggulan Bersaing. Yogyakarta, Penerbit Sekolah Tinggi Ilmu Manajemen YKPN. 2010

Amirullah. Pengantar Manajemen. Jakarta, Mitra Wacana Media. 2015

Ardana, I Komang dkk. Manajemen Sumber Daya Manusia. Yogyakarta, Graha Ilmu. 2012

Arif, Yusuf Hamali. Pemahaman Manajemenn Sumber Daya Manusia. CAPS (Canter for Academic Publishing Services). Yogyakarta, Buku Seru. 2016

Dessler, Gary. Manajemen Sumber Daya Manusia Human Resource Management.Jakarta, Salemba Empat. 2015

Donni Junni Priansa. Perncanaan dan Pengembangan SDM. Bandung. Alfabeta. 2014

Edy, Sutrisno. Manajemen Sumber Daya Manusia (Cetakan ke-9). Jakarta, Kencana. 2017

Eko, Widodo Suparno. Manajemen Pengembangan Sumber Daya Manusia. Yogyakarta, Pustaka Pelajar. 2015

Fahmi, Irham. Manajemen strategis Teori dan Aplikasi. Bandung, Alfabeta. 2013

Gaol, CHR. Jimmy L.A to Z. Human Capital (Manajemen Sumber Daya manusia) Konsep, Teori, dan Pengembangan dalam Konteks Organisasi Publik dan Bisnis. Jakarta, PT. Gramedia Widiasarana. 2014

Ghozali, Imam. Aplikasi Analisis Multivariate dengan Program IBM SPSS. Edisi lima. Semarang, Badan Penerbit UNDIP. 2013

Hasibuan, Malayu. Manajemen Sumber Daya Manusia Edisi Revisi. Jakarta, PT. Bumi Aksara. 2011

Hasibuan, Malayu. Manajemen Sumber Daya Manusia Edisi Revisi. Jakarta, PT. Bumi Aksara. 2012

Hasibuan, Malayu. Manajemen Sumber Daya Manusia Cetakan Kedua Puluh Satu. Jakarta, PT. Bumi Aksara. 2017

Kadarisman, M. Manajemen Pengembangan Sumber Daya Manusia Edisi Pertama Cetakan pertama. Jakarta, Rajawali Press. 2012

Mondy, R. Wayne. Manajemen Sumber Daya Manusia. Jakarta, Airlangga. 2012

Nugroho, Yohanes Anton. It's Easy... Olah Data dengan SPSS. Yogyakarta, PT. Skripta Media Creative. 2011

Rivai Vithzal \& Sagala, Ella Jauvani. Manajemen Sumber Daya Manusia untuk Perusahaan. Jakarta, PT. Raja Grafindo. 2010 
Sedarmayanti. Manajemen Sumber Daya Manusia Reformasi Birokrasi \& Manajemen Pegawai Negeri Sipil Edisi Revisi. Bandung, PT. Refika Aditama. 2017

Sedarmayanti. Manajemen Sumber Daya Manusia. Bandung, Refika Aditama. 2013

Sugiyono. Statistika Untuk Penelitian (Cetakan ke-16). Bandung, Alfabeta, 2010

Sugiyono. Metode Penelitian Kuantitatif, Kualitatif dan R\&D (Cetakan ke-22). Bandung, CV. Alfabeta. 2015

Sunyoto, Danang. Penelitian Sumber Daya Manusia: Teori, Kuesioner, Alat Statistik, \& Contoh Riset (cetakan pertama). Yogyakarta, CAPS (Center of Academic Publishing Service). 2015

Suwanto, \& Priansa, donni. Manajemen SDM dalam Organisasi Publik dan Bisnis. Bandung. Alfabeta. 2016

Wirawan. Evaluasi Kinerja Sumber Daya Manusia Teori Aplikasi dan Penelitian. Jakarta, Salemba Empat. 2012

Zainal, Veithzal Rivai, dkk. 2015. Manajemen Sumber Daya Manusia Untuk Perusahaan

Dari Teori Ke Praktik. Jakarta: Rajawali Pers. 2015

\section{Jurnal}

http://simki.unpkediri.ac.id/mahasiswa/file artikel/2017/5585fcb53a4e7a3b87e05ebc5a7ca6c $1 . \mathrm{pdf}$

http://ejournal.adbisnis.fisip-unmul.ac.id/site/wpcontent/uploads/2013/03/yuli\%20jurnal\%20(03-19-13-02-50-31).pdf

http://riset.unisma.ac.id/index.php/jrm/article/download/890/937

https://ejournal3.undip.ac.id/index.php/djom/article/view/20909 